\title{
Reproducibility of Diagnosis of ASC-US, Reflection of Diagnostic Criteria to Cervical Histopathological Results and Investigation of p16 Antibodies in Cervical Biopsies
}

\section{ASC-US Tanılı Hastalarda Tekrarlanılabilirlik, Tanı Kriterlerinin Servikal Biyopsiye Yansıması ve Servikal Biyopsilerde p16 Antikoru Araştırılması}

\author{
Zehra Edebal' ${ }^{1}$, Egemen Akıncıoğlứ ${ }^{2}$, Mine Kiselii ${ }^{3}$, Handan Doğan ${ }^{2}$, \\ Aslı Yarcı Gürsoy ${ }^{3}$, Ömür Ataoğlu ${ }^{4}$
}

\author{
${ }^{1}$ Beyhekim Devlet Hastanesi, Patoloji Bölümü, Konya, Türkiye \\ ${ }^{2}$ Ufuk Üniversitesi Tıp Fakültesi, Patoloji Ana Bilim Dalı, Ankara, Türkiye \\ ${ }^{3}$ Ufuk Üniversitesi Tıp Fakültesi, Kadın Hastalıkları ve Doğum Ana Bilim Dalı, Ankara, Türkiye \\ ${ }^{4}$ Özel Mikro-Pat Patoloji Laboratuarı, Ankara, Türkiye
}

\section{ÖZET}

Giriş ve Amaç: Önemi belirlenemeyen atipik skuamöz hücreler (ASC-US) tanısı koyduğumuz Papanicolau (PAP) smear örneklerinin, tekrar üretilebilirliği, Bethesda tanı kriterlerinden hangilerini karşıladığı ve tanı kriterlerinin servikal histopatolojiye yansımasını araştırmayı planladık. Ayrıca Pap smear sonucu ASC-US olan hastaların servikal biyopsi örneklerinde p16 antikor varlığı araştıııldı.

Yöntem ve Gereçler: Bölümümüzde 2006-2013 yılları arasında ASC-US tanısı konulan hastalardan servikal histopatolojik incelemesi yapılmış olan 33 hastayı çalı̧̧mamıza dahil ettik. Tüm Pap smear örnekleri iki patolog tarafindan, aynı anda tekrar değerlendirildi. Her örneğin 2001 Bethesda ASC-US tanı kriterlerinden hangilerini karşıladığı ayrı ayrı belirlendi. Her biyopsi örneği p16 antikoru ile boyandı.

Bulgular: Bölümümüzde Pap smear sonucu ASC-US olan raporların tekrar üretilebilirlik oranı \%88 olarak bulundu. Bethesda'nın 4 tanı kriterinden herhangi biri için, CIN 1 ve malignite yönünden negatif vakalarda görülme sıklıkları bakımından anlamlı bir farklılığa rastlanamadı ( $p>0,05)$. Tüm ASC-US vakalarında örnek başına pozitif tanı kriteri sayısı ortalaması ise $2,7 \pm 0,9$ 'dur. Malignite yönünden negatif olarak raporlanmış ve CIN olarak raporlanmış vakalarda ortalama kaç kriterin bir arada pozitif olduğu incelendi, istatistiksel olarak anlamlı bir farklılık olmadığı görüldü. ASC-US tanısı konulan vakaların histopatolojik örneklerinde p16 boyanma oranı \%18 olarak bulundu. Çalışmamızda p16 immünohistokimyasal boyamanın CIN tanısı koymada duyarlılığ $1 \% 46$, özgüllüğü ise \%100'dür.

Tartışma ve Sonuç: Pap smear incelemelerinde Bethesda sistemi kullanılarak ASC-US tanısı konulan vakalarımızın \%39'unda altta yatan bir servikal intraepitelyal neoplazi bulunduğu saptanmıştır. Bethesda ASCUS tanı kriterlerinden hiçbiri olası neoplastik değişiklikleri öngörmede tek başına diğer kriterlerden üstün değildir. ASC-US tanısı konulurken Bethesda tanı kriterlerinin her birinin varlığı ayrı ayrı araştırılmalı ve en az 2 , tercihen 3 kriterin pozitif olması tercih edilmelidir. p16 antikorunun yalancı pozitiflik oranının oldukça düşük olduğu, bu sayede neoplazi potansiyeli taşıyan vakaların belirlenmesinin kolaylaştığı görülmüştür. İlerleyen y1llarda p16 boyanmasının sitopatolojiyle birlikte kullanılabilecek önemli bir tanısal araç haline geleceği düşünülmektedir.

Anahtar Kelimeler: ASC-US, Servikal intraepitelial neoplazi, p16 (INK4A), Pap smear

\begin{abstract}
Introduction: We aimed to investigate reproducibility of diagnosis, presence of Bethesda criteria and their reflection to histopathology in Papanicolau (PAP) smears with atypical squamous cells of undetermined significance (ASC-US). We also searched for p16 antibody positivity in cervical biopsy specimens of the patients with diagnosis of ASC-US.

Methods: 33 patients who had undergone cervicopathologic evaluation were chosen from patients given ASCUS diagnosis in our department between 2006 and 2013 for this study. All the Pap smear specimens were reevaluated simultaneously by two pathologists. The specimens were evaluated for positivity of each Bethesda ASC-US diagnostic criteria separately. The biopsy specimens were stained with p16 antibody.

Results: The reproducibility rate of cytology reports for Pap smear specimens diagnosed as ASC-US was found $88 \%$. Neither of the Bethesda diagnostic criteria showed significant precedence over each other for frequency of
\end{abstract}


presence in cervical intraepithelial neoplasia (CIN) 1 and non-malignant cases $(\mathrm{P}>0.05)$. Mean number of positive diagnostic criteria was $2.7 \pm 0.9$ when ASC-US cases were considered altogether. There was no statistically significant difference between CIN cases and non-malignant cases for average number of positive diagnostic criteria. Histopathology specimens of these cases had an $18 \%$ of staining rate for p16 antibody. It was found that immunohistochemical staining had a $46 \%$ of sensitivity and $100 \%$ specificity for diagnosing CIN.

Discussion and Conclusion: An underlying cervical intraepithelial neoplasia was determined in $39 \%$ of cases diagnosed as ASC-US using Bethesda diagnostic criteria. Neither of the Bethesda diagnostic criteria exhibited superiority alone in foreseeing probable neoplastic changes. Presence of each Bethesda diagnostic criteria should be analyzed independently and existence of at least two, favorably three criteria should be preferred for diagnosing ASC-US. p16 antibody showed low false positive rate, thus distinguishing the cases with a potential of neoplastic formation became rather easy. p16 staining will become an important diagnostic instrument when used concomitant with cytopathology.

Keywords: ASC-US, Cervical intraepithelial neoplasia, p16 (INK4A), Pap smear

\section{Giriş:}

Serviks kanseri dünya çapında her y1l 528 bin yeni vakanın görüldüğü ve 266 bin kadının hayatını kaybetmesine yol açan önemli bir sağlık sorunudur. Kadınlarda görülen tüm kanserlerin yaklaşık \%12'si serviks kanseridir (1). Sağlık Bakanlığı Türkiye Halk Sağlığ1 Kurumu'nun verilerine göre Türkiye'deki kadınlarda serviks kanserinin tüm kanserler içinde görülme oranı \%2,7 dir (2).

Serviks kanseri taramasında Pap smear testi kullanılmaktadır. Pap smear raporlarının standardizasyonu için geliştirilen Bethesda sistemi, 2001 yılında güncellenerek çeşitli yeni tanımlamalara kavuşmuştur. Atipik skuamoz hücreler (ASC) bu sistemde önemi bilinemeyen (ASC-US) ve yüksek dereceli skuamoz intraepitelyal lezyon dişlanamıyor (ASC-H) olarak iki farkl1 siniflamaya tabi tutulmuştur (3). ASC-US tanısı, patologlar arasında tekrar üretilebilirliği düşük ve tanı kriterleri üzerindeki tartışmaların halen devam ettiği bir konudur. Buna rağmen tüm Pap smear incelemelerinin yaklaşık \%5 kadarı ASC-US olarak raporlanmakta ve bu vakalar takip edildiğinde intraepitelyal lezyon veya maligniteye rastlanamadığı gibi değişen oranlarda servikal intraepitelyal lezyonlar (CIN) da görülebilmektedir (4). Pap smear ve servikal biyopsi sonuçlarında gözlenen bu değişkenlik ve tekrarlanabilirlik sorunları, Human Papilloma Virusu (HPV-DNA), p16INK4A (p16), Ki67 gibi yeni testlerin ortaya çıkmasına yol açmıştır (5).

HPV, serviks kanseri ve CIN vakalarinin $\% 90$ 'indan fazlasinda bulunmaktadir (6). p16, insanlarda 9. kromozomda bulunan CDKN2A geninde kodlanmış bir tümör baskılayıcı proteindir.
Özellikle, HPV ile enfekte olmuş ve hücre döngüsü kontrolünü yitirmiş hücrelerin sitoplazmalarında ve çekirdeklerinde birikir ( 7 , 8). $\mathrm{Bu}$ nedenle p16, duyarlı ve özgül bir neoplastik transformasyon belirteci olarak kullanılmaktadır.

$\mathrm{Bu}$ çalışmada, ASC-US tanısı konulan Pap smear örneklerinin, tekrar üretilebilirliği, Bethesda tanı kriterlerinden hangilerini karşıladığı, $\tan 1$ kriterlerinin servikal histopatolojiye yansıması ve servikal biyopsi örneklerinde p16 antikoru varlığının araştırılması planland1.

\section{Gereç ve Yöntem:}

Ufuk Üniversitesi Tip Fakültesi Patoloji Anabilim Dalı'nda 2006-2013 yılları arasında servikal smear incelemesi yapılmış olan tüm hastaları geriye dönük olarak tarandı ve ASCUS tanis1 konulan hastalardan servikal histopatolojik incelemesi yapılmış olanlar çalışmaya dahil edildi.

ASC-US tanısı konulmuş ve serviks biyopsisi alınmış vakalara ait tüm Pap smear örnekleri iki patolog (Z.E - E.A) tarafından tekrar değerlendirmeye alındı. Her örneğin 2001 Bethesda ASC-US tan1 kriterlerinden hangilerini karşıladığı ayrı ayrı belirlendi (9). $\mathrm{Bu}$ vakaların biyopsi materyallerine ait histopatoloji raporları incelenerek tanılarına göre gruplandırıldı.

p16 immünohistokimyasal boyamas1 için Becton Dickinson Pharmingen ${ }^{\mathrm{TM}}$ purified Mouse anti-human p16 (BD and Co.,New Jersey, ABD) G175-405 klonu kullanıldı. Boyama işlemi Ventana BenchMark XT (Ventana Medical Systems, Inc., Arizona, ABD) cihazı kullanılarak gerçekleştirildi. Dokular 4 mikron kalınlığında kesildi. 
Hazırlanan kesitler deparafinizasyon için $60^{\circ} \mathrm{C}$ 'de 45 dakika etüvde bekletildi. Preparatlar Ventana BenchMark XT cihazına yerleştirilerek cihaz üzerinde de yeniden otomatik deparafinizasyon gerçekleştirildi. Preparatlar "cell conditioning" işlemine tabi tutuldu. Bunun için sırasıyla kısa ayarda 8 dakika, orta ayarda 30 dakika ve standart ayarda 60 dakika işlem uygulandı. Önceden 1:20 oranında titre edilerek hazırlanmış olan p16 boyası kesitlere damlatıld1. Primer antikor inkübasyonu süresi 1 saat olarak ayarlandi. Sonra sirasiyla "counter stain" (hematoksilen 8 dakika) ve "post-counter stain" (bluing reagent - 4 dakika) işlemleri uygulanarak boyama işlemi tamamland. Hazırlanan preparatlar bir patolog (Z.E) tarafindan mikroskop altında incelendi. \%25 ve üzeri diffüz boyanma pozitif olarak kabul edildi (10).

Elde edilen veriler "SPSS 11.5 for Windows" yazılımıyla değerlendirildi (SPSS Inc., Chicago, U.S.A.). Sitolojik incelemede Bethesda ASC-US tanı kriterlerinin pozitiflik oranının CIN pozitif vakalardaki frekans dağılımını incelemek ve p16 boyanma oranını değerlendirmek için ki-kare testi ve Yate's süreklilik düzeltmesi kullanıldı. $\mathrm{P}<0,05$ olan değerler istatistiksel olarak anlamlı kabul edildi.

\section{Bulgular:}

2006-2013 yılları arasında Ufuk Üniversitesi Tıp Fakültesi Patoloji Anabilim Dalı'nda ASCUS tanısı konulmuş ve sonrasında servikal histopatolojik inceleme gerçekleştirilmiş toplam 33 hasta çalışmaya dahil edildi. Hastaların yaş ortalaması $38 \pm 11$ 'di. Otuzüç hastanın 13'ünün (\%39) histopatolojik tanıs1 CIN olarak bulundu. $\mathrm{Bu}$ hastalardan 11'i CIN1, ikisi ise fokal CIN2 odakları taşıyan CIN1 olarak raporlanmıştı. Histopatolojik değerlendirme sonucunda CIN tanısı konulmuş hastalar ile malignite yönünden negatif olarak raporlanmış hastaların yaşları arasında istatistiksel olarak anlamlı bir farkl1lık izlenmedi (Sirasıyla $37 \pm 12$ ve $39 \pm 10$, p $>0,05$ ). ASC-US tanıs1 konulmuş 33 Pap smear örneği yeniden incelendi. İkinci değerlendirme sonucunda iki ASC-US tanısı intraepitelyal lezyon veya malignite negatif (NILM) olarak, diğer iki ASC-US vakası da düşük dereceli intraepitelyal lezyon (LSIL) olarak değerlendirildi. $\mathrm{Bu}$ hastaların histopatolojik incelemelerinde skuamöz intraepitelyal neoplazi saptanmamıştı. Yeniden değerlendirilen 33 vakadan 29'unun ASC-US tanısı değişmedi. Bu şekilde, Ufuk Üniversitesi Tıp Fakültesi Tıbbi Patoloji Anabilim Dalı'nda Pap smear sonucu ASC-US olarak bildirilen raporların tekrar üretilebilirlik oranı $\% 88$ olarak bulundu.

Bethesda ASC-US tan1 kriterlerinin sitolojik dağılımının histopatolojik tanıyla bir ilişkisi olup olmadığı incelendi. Bethesda'nın 4 tanı kriterinden hiçbiri için, CIN 1 ve malignite yönünden negatif vakalarda görülme sıklıkları bakımından anlamlı bir farklılığa rastlanmadı ( $>0,05)$ (Tablo 1). Malignite yönünden negatif olarak raporlanmış ve CIN olarak raporlanmış vakaların ortalama pozitif kriter sayısında istatistiksel olarak anlaml bir farklılık olmadığı görüldü ( $\mathrm{p}>0,05)$ (Tablo 2).

Olguların p16 boyanma oranlarına göre dağılımları Tablo 3'te izlenmektedir. ASC-US tanısı konulmuş ve histopatolojik olarak malignite yönünden negatif olan vakaların hiçbirinde p16 boyaması pozitif değildi. Bunun yanında, CIN1 ve CIN2 olarak raporlanmış 13 vakadan 6'sında (\%46) diffüz p16 pozitifliği gözlendi. Yedi vakada ise p16 negatif olarak kabul edildi (Resim1). Tüm vakalar birlikte değerlendirildiğinde, ASC-US tanis1 konulan vakaların histopatolojik örneklerinde p16 boyanma oranı \%18 olarak bulundu (Tablo 3).

$\mathrm{Bu}$ çalışmada p16 immünohistokimyasal boyamanın CIN tanısı koymada duyarlılığı $\% 46$, özgüllüğü ise \%100 olarak hesapland. Testin pozitif prediktif değeri $\% 100$, negatif prediktif değeri $\% 74$ olarak hesaplandi.

Resim 1: A) p16 Negatif Boyanma (x200) B) p16 Diffüz Pozitif Boyanma (x600).

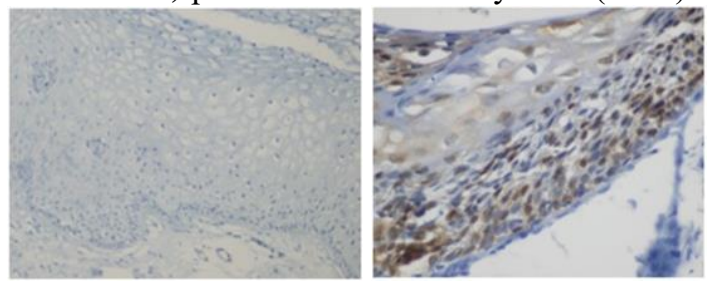


Tablo 1. Bethesda ASC-US Tanı Kriterlerinin Pozitiflik Oranlarının Dağılımları

\begin{tabular}{|c|c|c|c|}
\hline \multirow{2}{*}{$\begin{array}{c}\text { Bethesta ASC-US Tanı } \\
\text { Kriterleri }\end{array}$} & $\begin{array}{c}\text { Histopatolojik Tanı } \\
\text { CIN 1+ CIN 2* } \\
\text { (Toplam:13) }\end{array}$ & $\begin{array}{c}\text { Malignite Açısından } \\
\text { Negatif } \\
\text { (Toplam: 20) }\end{array}$ & \multirow{2}{*}{ TOPLAM } \\
\cline { 2 - 4 } $\begin{array}{c}\text { Çekirdeklerin kapladı̆̆ alan } \\
\text { normal intermediate skuamoz } \\
\text { hücre çekirdeğine göre 2,5-3 kat } \\
\text { daha fazla }\end{array}$ & 13 & 18 & $\mathbf{3 1}$ \\
\hline $\begin{array}{c}\text { Çekirdek/Sitoplazma alan oranı } \\
\text { hafifçe artmış }\end{array}$ & 11 & 15 & $\mathbf{2 6}$ \\
\hline $\begin{array}{c}\text { Minimal nükleer hiperkromazi ve } \\
\text { kromatin dağ1lımında veya } \\
\text { çekirdek şeklinde düzensizlik }\end{array}$ & 10 & 14 & $\mathbf{2 4}$ \\
\hline $\begin{array}{c}\text { Dens oranjofilik sitoplazma } \\
\text { ("atipik parakeratoz") ile ilişkili } \\
\text { nükleer anormallikler }\end{array}$ & 4 & 4 & $\mathbf{8}$ \\
\hline
\end{tabular}

*CIN: Servikal intraepitelyal neoplazi

Tablo 2. ASC-US Tanı Kriterlerinin Örnek Başına Ortalama Pozitiflik Oranları

\begin{tabular}{|c|c|c|c|}
\hline \multirow{2}{*}{} & \multicolumn{2}{|c|}{ Histopatolojik Tanı } & \multirow{2}{*}{ TOPLAM } \\
\cline { 2 - 3 } & CIN 1+CIN 2* & $\begin{array}{c}\text { Malignite Aç1sından } \\
\text { Negatif }\end{array}$ & \\
\hline $\begin{array}{c}\text { Pozitif Kriter Say1S1 } \\
\text { (Ortalama } \pm \text { SS })\end{array}$ & $2,9 \pm 0,8$ & $2,5 \pm 1,0$ & $\mathbf{2 , 7} \pm \mathbf{0 , 9}$ \\
\hline
\end{tabular}

*CIN: Servikal intraepitelyal neoplazi

Tablo 3. p16 Boyanma Oranının Histopatolojik Tanıya Göre Dağılımı

\begin{tabular}{|l|c|c|c|}
\hline \multirow{2}{*}{ p16 boyanma } & \multicolumn{2}{|c|}{ Histopatolojik Tanı } & \multirow{2}{*}{ TOPLAM } \\
\cline { 2 - 3 } & CIN 1+CIN 2* & Malignite Açısından Negatif & $\mathbf{6}$ \\
\hline Pozitif & 6 & 0 & $\mathbf{2 7}$ \\
\hline Negatif & 7 & 20 & $\mathbf{3 3}$ \\
\hline TOPLAM & $\mathbf{1 3}$ & $\mathbf{2 0}$ & \\
\hline
\end{tabular}

*CIN: Servikal intraepitelyal neoplazi

\section{Tartışma:}

Pap smear, servikal kökenli neoplazilerin taranmasında ve serviks kanser insidansının azaltılmasında en önde gelen testtir. Ancak Pap smear, sitolojinin en tartışmalı konularından biridir. Testi değerlendiren kișiler aras1 değişkenliğin yüksek oluşu ile yüksek yanlış negatiflik ve pozitiflik oranları başta gelen nedenlerdendir. Değerlendiriciler arası farklılık \%50 dolaylarındadır (11). Literatürde, yanlıș negatiflik oranlarının \%20-30, yanlış pozitiflik oranlarının \%70'leri bulduğunu bildiren araştırmalar mevcuttur (12). Bu çalışmada ASC-US tanısı konulmuş vakaların tekrar üretilebilirlik oran1 \%88 olarak bulunmuştur. Literatüre göre bu oranın hayli yüksek olduğu görülmektedir. Olgu sayısının nispeten az olmasıyla birlikte, bölümümüzde çalışan patolog sayısının az olması dolayısıyla daha fazla etkileşimde bulunmaları oranın yüksek olmasının nedenleri olabilir.

Çalışmamızda 33 ASC-US vakasının biyopsi sonuçlarının 11'i CIN1, 2'si de CIN2 olarak değerlendirilmiştir. Geriye kalan malignite yönünden negatif olan 20 vaka ise kronik servisit, inflamasyona bağlı reaktif değişiklikler, atrofik değişiklikler, aktif kronik servisit, spesifik patoloji içermeyen çok katlı yassı epitel fragmanları, çok katlı yassı epitel metaplazisi gibi tanılar almıştır. $\mathrm{Bu}$ tanılar servikovajinal smear de ASC-US tanis1 konulmasina neden olabilecek skuamöz hücre değişiklikleri içermekte ve neoplastik değişiklikler taşıyan vakaların yakalanma oranını azaltmaktadır. Ayrıca, biyopsinin 
alındığı bölgenin lezyonu temsil etmeyebileceği de akılda tutulmalıdır. $\mathrm{Bu}$ çalışmada ASC-US tanısının neoplastik değişiklikleri yakalama anlamında başarı oranı \%39 (CIN1: \%33, CIN2: \%6) olarak bulunmuştur.

Bethesda ASC-US tanı kriterleri CIN tanısı koyma açısından karşılaştırıldığında dört kriterden herhangi birinin diğerine üstün olmadığı ve bir kriterin tek başına tanısal olmadığ1 görülmüştür. Biyopsi sonucuna göre malignite açısından negatif olanlar ile SIL tanılı olanlar arasında örnek başına ortalama pozitif kriter sayısında anlamlı bir farklılık bulunmamıştır. Tüm örneklerde ortalama pozitif kriter sayısının 2,7 oluşu da ASC-US tanısı koymak için Bethesda tanı kriterlerinin en az ikisinin, çoğunlukla da üçünün bir arada görülmesinin daha sağlıklı bir değerlendirmeye olanak sağlayacağını düşündürmüştür. Dolayısıyla, ASC-US tanıs1 konulurken tariflenen her 4 kriterin de Pap smear örneğinde varlığı ya da yokluğu ayrı ayr1 araştırılmalıdır.

ASC-US tanıs1 verilen olguların yönetiminde, HPV testi yoksa, bir süre sonra sitoloji tekrarı veya kolposkopik inceleme sonrası biyopsi yapılması önerilmektedir (13). ASC-US tanıs1 verilen olgularin altı aylık periyot sonrasi servikovajinal smearlerinin tekrarlandığı bir çalışmada \% 74' ünde ASCUS tanısı değişmemiş, \% 18'inde progresyon görülürken, $\%$ 8'inde sitolojik bulgular gerilemiştir. Progresyon görülen olguların hiçbirinde HSIL gelișmemiștir (14). Kolposkopi sonrası biyopsi yapılan olguları incelediğimiz çalışmamızda da ASC-US tanısı verilen olguların biyopsilerinde CIN3 tan11 olgu yoktur. Fakat ASC-US tanisı konulan hastaların servikal biyopsilerinde yüksek dereceli lezyon (HSIL) varlığının araştırıldığı başka bir çalışmada, skuamöz intraepitelyal lezyon (SIL) varlığ1 \%28,3 (CIN1: \%20,6; CIN2: \%4,5; CIN3 \%3,2) olarak bulunmuştur (15). Bethesda ASC-US tanı kriterlerine dikkat edildiğinde hemen tedavi gerektirebilecek yüksek dereceli lezyonlar yanlışlıkla ASC-US tanıs1 almayacaktır.

Yapılan bir meta-analizde servikal sitohistopatolojide p16 boyamayla ilgili yapılmış çalışmalar ele alınmış ve bunların arasından 61'i değerlendirmeye uygun bulunarak incelenmiştir. $\mathrm{Bu}$ araştırmaların büyük kısmında p16 pozitifliği için eşik değerin belirlenmesinde, çalışmamızda kullanılan Klaes ve ark.'ın yaptığı çalışmanın referans alındığı belirtilmiştir (10). Genel olarak ASCUS tanılı olguların biyopsilerinde $\% 45$ oranında p16 pozitifliği bulunduğu bildirilmiş, sitolojik tanının ciddiyeti arttıkça p16 pozitiflik oranının da yükseldiği görülmüştür. Histolojik incelemelerde ise normal biyopsilerin \%2'sinde, CIN1 vakalarının \%38'inde, CIN2 vakalarının \%68'inde ve CIN3 vakalarının $\% 82$ 'sinde p16'nın pozitif olarak bildirildiği görülmüştür (8). Lezyonun derecesi yükseldikçe p16 antikoru boyanma oranı da artmaktadır. Diğer bir çalışmada ise 15 skuamöz intraepitelyal neoplazi olgusundan 8'inde p16 boyanması izlenmiştir (16). Çalışmamızda CIN 3 olgusu bulunmadığ 1 için vakalarımızda bulduğumuz $\% 46$ pozitif boyanma oranı literatürdeki düşük dereceli lezyonlardaki p16 boyanmasiyla benzerdir.

Sonuç olarak, bu çalışmada Pap smear incelemelerinde Bethesda sistemi kullanılarak ASC-US tanıs1 konulan vakaların \%39'unda altta yatan bir SIL bulunduğu saptanmıştır. Bethesda ASC-US tanı kriterlerinden hiçbiri, olası neoplastik değişiklikleri öngörmede tek başına diğer kriterlerden üstün değildir. ASCUS tanis1 konulurken Bethesda tan1 kriterlerinin her birinin varlığ ayrı ayrı araştırılmalı ve en az 2, tercihen 3 kriterin pozitif olmas1 tercih edilmelidir. Ayrıca, immünohistokimyasal p16 antikoru çalışmasının yalancı pozitiflik oranının oldukça düşük olduğu, bu sayede neoplazi potansiyeli taşıyan vakaların belirlenmesinin oldukça kolaylaştığı görülmüştür. İlerleyen yıllarda p16 boyanmasının sitopatolojiyle birlikte kullanılabilecek önemli bir tanısal araç haline geleceği düşünülmektedir.

Teşekkür: Prof. Dr. Aytaç Gököz hocamızı saygıyla anıyoruz. Çalışmamızda emeği geçen Osman Başhan'a ve MOS Medikal Oluşum Sanayii ve Tic. Ltd. Şti.'ne teşekkür ederiz.

\section{Çıkar Çatışması: Yok}

\section{Kaynaklar:}

1. Ferlay J, Soerjomataram I, Dikshit R et al. Cancer incidence and mortality worldwide: source, methods and major patterns in GLOBOCAN 2012. Int $\mathrm{J}$ Cancer, 2015 Mar 1;136(5):E359-86 
2. Gültekin M, Boztaş G. Türkiye Kanser İstatistikleri. Ocak 2014

3. Solomon D, Davey D, Kurman R et al. The 2001 Bethesda System: terminology for reporting results of cervical cytology. JAMA, 2002;287(16):2114-9

4. Iavazzo C, Boutas I, Grigoriadis C, Vrachnis N, Salakos N. Management of ASCUS findings in Papanicolaou smears. A retrospective study. Eur J of Gynaecol Oncol. 2012;33(6):605-9

5. Keating JT, Cviko A, Riethdorf S. et al. Ki-67, Cyclin E, and p16 INK4 Are Complimentary Surrogate Biomarkers for Human Papilloma VirusRelated Cervical Neoplasia. Am J Surg Pathol. 2001;25(7):884-91

6. Walboomers JM, Jacobs MV, Manos MM et al. Human papillomavirus is a necessary cause of invasive cervical cancer worldwide. J Pathol. 1999;189(1):12-19

7. Wentzensen $\mathrm{N}$, von Knebel Doeberitz $\mathrm{M}$. Biomarkers in cervical cancer screening. Dis Markers. 2007;23(4):315-30

8. Tsoumpou I, Arbyn M, Kyrgiou M et al. p16INK4a immunostaining in cytological and histological specimens from the uterine cervix: a systematic review and meta-analysis. Cancer Treat Rev. 2009;35(3):210-20

9. Sherman ME, Abdul-Karim FW, Berek JS et al. Atypical Squamous Cells. In: Solomon D, Nayar R. The Bethesda System for Reporting Cervical Cytology (2nd edition). New York, USA: SpringerVerlag; 2004:67-87

10. Klaes R, Friedrich $T$, Spitkovsky $D$ et al. Overexpression of p16INK4A as a specific marker for dysplastic and neoplastic epithelial cells of the cervix uteri. Int J Cancer. 2001;92(2):276-84

11. Stoler MH, Schiffman M. Interobserver reproducibility of cervical cytologic and histologic interpretations: realistic estimates from the ASCUSLSIL Triage Study. JAMA 2001;285(11):1500-5

12. Fahey MT, Irwig L, Macaskill P. Meta-analysis of Pap test accuracy. Am J Epidemiol. 1995;141(7):680-9

13. Kyrgiou M, Kalliala I, Mitra A et al. Immediate Referral to Colposcopy Versus Cytological Surveillance for Low-Grade Cervical Cytological Abnormalities in the Absence of HPV Test: A Systematic Review and a Meta-Analysis of the Literature. Int J Cancer. 2016 Sep 7. Doi: 10.1002/ijc.30419

14. Jahic M, Jahic E. Diagnostic Approach to Patients with Atypical Squamous Cells of Undetermined Significance Cytologic Findings on Cervix. Med. Arch. 2016 Aug;70(4):296-8

15. Marcos Lopes AC, Campaner AB, Henrique LQ. Prevalence of High-Grade Intraepithelial Neoplasia in Patients with Cytology Presenting Atypical Squamous Cells of Undetermined Significance. Acta Cytol. 2016;60(2):139-44

16. Kava S, Rajaram S, Arora VK et al. Conventional Cytology, Visual Tests and Evaluation of P16(INK4A) as a Biomarker in Cervical Intraepithelial Neoplasia. Indian J Cancer. 2015 JulSep;52(3):270-5 